\title{
РОЛЬ ПРАКТИКИ ЕВРОПЕЙСКОГО СУДА ПО ПРАВАМ ЧЕЛОВЕКА В УНИФИКАЦИИ НАЦИОНАЛЬНОГО ЗАКОНОДАТЕЛЬСТВА ОБ ОБРАЗОВАНИИ
}

B ст. 46 Конституции РФ закреплено право каждого человека обращаться в межгосударственные органы по защите прав и свобод человека, если исчерпаны все имеющиеся внутригосударственные средства правовой защиты. Членство РФ в Совете Европы дает возможность гражданам защищать в Европейском Суде по правам человека права и свободы, закрепленные Конвенцией о защите прав человека и основных свобод от 4 ноября 1950 г. ${ }^{1}$ Конвенция позволяет гражданам подавать жалобы в Европейский Суд по правам человека самостоятельно или при помощи своих законных представителей.

В Европейской конвенции о защите прав и основных свобод гарантируется право на образование, закрепленное в ст. 2 Протокола № 1 (подписан в г. Париже 20 марта 1952 г.). Непосредственно в Конвенции закреплены права, которые тесно связаны с образованием: свобода мысли, совести и религии (ст. 9), свобода выражения мнения (ст. 10), свобода собраний и объединений (ст. 11); право на справедливое судебное разбирательство (ст. 6).

Согласно ст. 2 Протокола № 1, «никому не может быть отказано в праве на образование. Государство при осуществлении любых функций, которые оно принимает на себя в области образования и обучения, уважает право родителей обеспечивать такое образование и такое обучение, которые соответствуют их религиозным и философским убеждениям». Толкование этого положения неоднозначно. Отдельные авторы сужают поле защиты права на образование, преувеличивая значение второго предложения. Так, Н.Р. Косевич пишет: «Статья 2 Протокола № 1 к Европейской конвенции гарантирует

С3 РФ. - 2001. - № 2. - Ст. 163. общее, а не конкретное право на образование, носителем которого является тот, кто заинтересован в получении образования и кто может и должен извлечь из него пользу, т.е. в первую очередь ребенок»².

Право на образование содержит в себе и право на получение образовательных услуг любого уровня, включая профессиональное образование различных уровней ${ }^{3}$. Как сказано в Конвенции о признании квалификаций, относящихся к высшему образованию в Европейском регионе (ЕTS № 165) (Лиссабон, 11 апреля 1997 г.) $)^{4}$, высшее образование «служит ключевым фактором расширения и развития знаний» и «представляет собой исключительно ценное культурное и научное достояние как для каждого человека, так и для общества».

Прежде право на образование рассматривалось Судом как касающееся, преимущественно, «начального образования, а не обязательно занятий на продвинутом уровне, таких как технология» ${ }^{5}$.

\footnotetext{
2 Косевич Н.Р. Защита прав детей в практике Европейского суда по правам человека // СПС «КонсультантПлюс», 2011.

См.: Reid K. Practitionerrs guide to the European Convention on Human rights. London, 2004. - S. 269. § ІІВ-109. Цит. По: Коротаева А.М. Практика применения Европейской конвенции о защите прав человека и основных свобод: трудоправовой аспект // Российская юстиция. - 2010. - № 9. - С. 69-72.

4 Российская Федерация подписала данную Конвенцию 7 мая 1999 г., а 1 июля 2000 г. после ратификации стала ее полноправным участником // СЗ РФ. - 2000. - № 39. - Ст. 3836.

См.: Решение Европейской Комиссии от 13 марта 1975 г. (жалоба № 5962/72) по делу «Х. против Соединенного Королевства» (X. v. United Kingdom); Решение Европейской Комиссии от 17 января 1996 г. (жалоба № 21062/92) по делу «Крамелиус против Швеции» (Kramelius v. Sweden).
} 
Сегодня Европейский Суд отмечает: «... сложно представить себе, чтобы высшие учебные заведения, существующие в определенное время, не подпадали в сферу применения первого предложения статьи 2 Протокола № 1 к Конвенции. Хотя эта статья не обязывает Договаривающиеся государства создавать высшие учебные заведения, любое государство, их создающее, обязано обеспечить эффективное право на учебу в них. В демократическом обществе право на образование, столь необходимое для продвижения прав человека, играет настолько фундаментальную роль, что ограничительное толкование первого предложения статьи 2 Протокола № 1 к Конвенции не соответствует цели данной нормы (см., ... Постановление Европейского Суда по «Бельгийскому делу о языках», p. 33, §9; Постановление Европейского суда по делу «Делькур против Бельгии» (Delcourt v. Belgium) от 17 января 1970 г., Series A, № 11, p. 14, § 25)

Европейский Суд исходит из того, что и дошкольное образование подпадает под защиту. Так, еще в 1965 г. Европейская комиссия отметила, что, хотя сфера применения права, гарантированного ст. 2 Протокола № 1 к Конвенции, не была определена или уточнена в Конвенции, она включала, «для целей рассмотрения настоящего дела», “доступ к детскому дошкольному, начальному, среднему и высшему образованию» ${ }^{7}$.

Одним из оспариваемых в Европейском Суде по правам человека аспектов права на образование является право на язык обучения.

В деле «Катан и другие (Catan and Others) против Молдавии и России» ${ }^{8}$ обжаловалось закрытие школ, использующих латиницу, и запугивание учеников, желающих обучаться на родном языке. В Приднестровье, которое пыталось отделиться от Республики Молдова, в 1992 г. было принято законодательство, требовавшее использования кириллицы при письме на «молдавском» языке, а использование латиницы в школах было запрещено с 1994 г. С 2004 г. власти Приднестровья начали принимать меры, направленные на закрытие всех школ, использующих латиницу. Ученики, посещающие три школы, были вынуждены переехать в новые и предположительно неудовлетворительные помещения после конфронтации с властями, включав-

6 Постановление ЕСПЧ от 10 ноября 2005 г. по делу «Лейла Шахин (Leyla Sahin) против Турции» (жалоба № 44774/98) // $<$ http://www.echr.coe.int $>$.

\section{7 Там же.}

8 Постановление ЕСПЧ от 19 октября 2012 г. по делу «Катан и другие (Catan and Others) против Молдавии и России» (жалобы № 43370/04, 8252/05 и 18454/06) // Бюллетень Европейского Суда по правам человек. 2013. № 3. шей вторжение полиции в здания в целях изгнания из них учеников, родителей и учителей.

В своей жалобе в Европейский Суд заявители ссылались на трудности, испытываемые учениками, желающими обучаться на официальном молдавском языке и в соответствии с учебной программой Министерства образования Молдавии и на дискриминационное обращение. Суд признал нарушение требований ст. 2 Протокола № 1 к Конвенции о защите прав человека и основных свобод.

В деле «Темел и другие против Турции» ${ }^{9}$ студенты были отчислены из университета за петиции с требованием введения факультативного изучения курдского языка. Они безуспешно просили приостановить исполнение дисциплинарных решений в их отношении. Их ходатайства об отмене решений были первоначально отклонены судами на том основании, что петиции могли породить поляризацию по языковому, национальному, религиозному или конфессиональному признаку, и что они представляли собой новую стратегию гражданского неповиновения Рабочей партии Курдистана (РКК, незаконная вооруженная организация). В дальнейшем судебное решение было отменено.

Европейский Суд по правам человека постановил, что отчисление заявителей из университета представляло собой ограничение их права на образование. Основным является вопрос соразмерности. Заявители не совершили каких-либо предосудительных действий, они не прибегали к насилию и не пытались нарушить мир или порядок в университете. Они были привлечены к ответственности лишь за подачу петиций и за взгляды, выраженные в них. Однако ни их взгляды, ни форма их выражения не могут считаться деятельностью, способной привести к поляризации университетского сообщества на языковой, национальной, религиозной или конфессиональной основе. Хотя право на образование в принципе не исключает применения дисциплинарных мер, включая временное или постоянное отчисление из учебного заведения, с целью обеспечения соблюдения его внутренних правил, такие меры не должны ущемлять существо права или противоречить иным правам, провозглашенным в Конвенции или Протоколах к ней. В настоящем деле заявители были отчислены из университета в результате осуществления своего права на свободу выражения мнения. Применение такой дисциплинарной меры не могло рассматриваться как разумное или со-

\footnotetext{
9 Постановление ЕСПЧ от 3 марта 2009 г. по делу «Темел и другие против Турции» (Temel and Others v. Turkey) (жалоба № 36458/02) // Бюллетень Европейского Суда по правам че-
} ловека. 2009. № 8. 
размерное. Хотя санкция была впоследствии отменена как незаконная, Европейский Суд «находит достойным сожаления, что к этому моменту заявители уже пропустили один или два семестра учебы, и в результате национального разбирательства они не получили возмещения по данному основанию».

Одно из дел было связано с обращением цыган в связи с тем, что цыганские дети были помещены в отдельные цыганские классы вследствие недостаточного знания ими хорватского языка ${ }^{10}$. Суд не усмотрел нарушения права на образование, отметив, прежде всего, что образование заявителей было не хуже, чем у других учеников, посещавших ту же школу, учебная программа для цыган и прочих учеников ничем не отличалась. Кроме того, перевод учеников из цыганских в смешанные классы представлял собой обычную практику, что подтверждается опытом первых девяти заявителей. Оставшиеся заявители никогда не просили о переводе в смешанные классы и не возражали против пребывания в цыганском классе. Последние пять заявителей по-прежнему посещали младшие классы, где вопрос об их переводе в смешанные классы был преждевременным с учетом причины их зачисления в класс для цыган, а именно недостаточного владения хорватским языком. Таким образом, заявители не были лишены права посещать школу и получать образование, и обеспеченное им образование было адекватным и достаточным.

В деле «Пономарев против Болгарии» ${ }^{11}$ обжаловалось исключение иностранных граждан из средней школы в связи с их неспособностью уплатить сбор, установленный для лиц, не имеющих статуса постоянного проживания. Европейский Суд, признал, что образовательную деятельность сложно организовать, и ее функционирование требует существенных затрат и что государство обязано обеспечивать равновесие между образовательными нуждами лиц, находящихся под его юрисдикцией, и его ограниченной способностью давать им пристанище. Однако нельзя игнорировать тот факт, что, в отличие от некоторых иных государственных услуг, образование представляет собой право, которое пользуется прямой защитой Конвенции. Оно также является крайне специфическим типом государственной услуги, которая не только непосредственно служит интересам лии, использу-

10 Постановление ЕСПЧ по делу «Оршуш и другие против Хорватии (Orsus and Others v. Croati) (жалоба № 15766/03) // Бюллетень Европейского Суда по правам человека. 2008. № 12.

11 Постановление ЕСПЧ от 21 июня 2011 г. по делу «Пономарев против Болгарии» (Ponomaryov v. Bulgaria) (жалоба № 5335/05) // Бюллетень Европейского Суда по правам человека. 2011. № 12. ющих ее, но и осуществляет более широкие социальные функции и является необходимой для продвижения прав человека.

Свобода усмотрения государства в этой сфере возрастает вместе с уровнем образования обратно пропорционально важности этого образования для заинтересованных лиц и общества в целом. Так, на уровне высшего образования, которое до сих пор остается необязательным для многих людей, более высокая плата для иностранных граждан - и, более того, плата в целом - представляется обычным явлением и может при настоящих обстоятельствах рассматриваться как полностью оправданная. Обратная ситуация имеет место с обучением в начальной школе, которое обеспечивает грамотность и умение считать, а также интеграцию в общество и первые знания о нем и является обязательным в большинстве стран. Среднее образование, о котором шла речь в деле заявителей, находится меж двух указанных противоположностей. Однако по мере продвижения все большего количества стран к тому, что описывается как "основанное на знаниях" общество, среднее образование играет растущую роль в успешном личностном развитии и в социальной и профессиональной интеграции заинтересованных лиц. Действительно, в современном обществе наличие лишь базовых знаний и навыков составляет препятствие для личного и профессионального развития и препятствует заинтересованным лицам в приспособлении к их окружению, с далеко идущими последствиями для их социального и экономического благополучия. Эти соображения свидетельствуют в пользу Европейского Суда, применяющего более строгий контроль при оценке пропорциональности меры, затрагивающей заявителей.

Заявители не находились в положении лиц, прибывших в страну незаконно и затем предъявивших права на использование ее государственных услуг, включая бесплатное школьное образование. Даже без постоянного вида на жительство власти не имели существенных возражений против их нахождения в Болгарии или серьезного намерения депортировать их. Таким образом, любые соображения, касающиеся необходимости остановить или повернуть вспять процесс незаконной иммиграции, явно неприменимы к делу заявителей. Однако болгарские власти не приняли ни один из этих факторов во внимание. Действительно, законодательство не предусматривало возможности ходатайствовать об освобождении от оплаты школьного обучения. Таким образом, при особых обстоятельствах дела требование о внесении заявителями платы за среднее образование в связи с 
их гражданским и иммиграционным статусом не было оправданным.

Следующее дело касалось совместимости образования в разных странах. В деле «Кек против Турции» ${ }^{12}$ обжаловался отказ в признании обучения по врачебной специальности, начатого в другой стране, в связи с несоответствием определенным критериям. Суд не признал нарушения ст. 2 Протокола № 1 к Конвенции.

Заявительница получила в Болгарии общее медицинское образование и начала прохождение последипломного обучения по врачебной специальности. Ее диплом был признан в Турции, где она работала врачом, однако период последипломного обучения по врачебной специальности в Болгарии не был засчитан в связи с несоответствием определенным критериям.

Европейский Суд указал, что отказ властей зачесть период последипломного обучения по специальности, пройденного заявительницей в Болгарии, не может приравниваться в настоящем деле к ограничению права на образование.

В деле «Мюрсель Эрен против Турции» ${ }^{13}$ обжаловалось аннулирование успешных результатов вступительного экзамена в университет абитуриента из-за низких результатов экзаменов, сданных им в предыдущие годы.

После окончания средней школы заявитель сдавал экзамен для поступления в университет первый раз в 1994 г. Экзамен, который организовывался на ежегодной основе Центром по отбору и направлению на учебу студентов (ЦОНУС) при Совете по вопросам высшего образования, состоит из проверки знаний на двух этапах путем проведения теста с выбором из нескольких вариантов ответа. В своих попытках сдать экзамен в последующие два года заявитель также провалился на первом этапе экзамена. В 1997 г. заявитель для подготовки к экзамену занимался на частных репетиторских курсах. В том году он прошел первый этап экзамена и стал сдавать экзамен на втором его этапе. После второго этапа он поверил, что экзамен он сдал. Однако его имя не фигурировало в списке лиц, сдавших экзамен. Впоследствии ЦОНУС уведомил его о том, что он был в числе абитуриентов, прошедших второй этап экзамена, которые имели наилучшие результаты, но, что его результаты были аннулированы по рекомендации научного совета, состоящего из трех

12 Постановление ЕСПЧ от 19 октября 2006 г. по делу «Кек против Турции» (Kok v. Turkey) (жалоба №1855/02) // Бюллетень Европейского Суда по правам человека. - 2007. - № 4.

13 Постановление ЕСПЧ от 7 февраля 2006 г. по делу «Мюрсель Эрен против Турции» (Mhrsel Eren v. Turkey) (жалоба № 60856/00) // Бюллетень Европейского Суда по правам человека. - 2006. - № 9. профессоров, который счел, что ввиду его низких результатов в предшествующие годы нельзя было объяснить его нынешние отличные результаты.

В Европейском Суде государство не оспаривало, что заявитель был лишен возможности доступа к университетскому образованию, несмотря на то, что он получил требуемые для прохождения в вуз отметки. Государство-ответчик не указало на какую-либо правовую основу усмотрения ЦОНУСа в аннулировании результатов экзаменов абитуриентов на том основании, что они не могут объяснить свою успешную сдачу экзамена. Как бы то ни было, любой нормативный базис, предоставляющий такое широкое усмотрение, может создать состояние правовой неопределенности, несовместимое с принципом верховенства права и нанести ущерб самой сути права человека на образование.

Следует также иметь в виду, что результаты экзаменов абитуриентов подсчитывались по тщательно отработанной методике, которая не оставляла администрации ЦОНУСа свободы маневра для того, чтобы заменить результаты компьютеризированной системы оценки в баллах экзаменационных работ своими личными суждениями. Кроме того, формулировки Правил ЦОНУСа позволяли добросовестному абитуриенту сформировать законное ожидание, что ему удастся поступить на учебу в университет, поскольку он получил необходимое число баллов на экзамене. В отсутствие каких-либо доказательств того, что заявитель пользоваться шпаргалками на экзаменах, или даже в отсутствие прямого обвинения в его адрес в недобросовестности на экзаменах и памятуя о неоспоренном объяснении, представленном Европейскому Суду, что он подготовился к экзаменам 1997 г., посещая частные репетиторские занятия, заключение, к которому пришел научный совет, что высокие результаты заявителя, полученные им на экзамене, не имеют объяснения, является несостоятельным.

Суд признал нарушение права на образование.

В деле «Али против Соединенного Королевства» ${ }^{14}$ обжаловалось исключение ученика из средней школы на длительный срок в связи с уголовным расследованием происшествия в школе. Суд не усмотрел нарушений Конвенции, указав, что мера, состоящая в приостановлении обучения ученика по причинам, не связанным с внутренними правилами школы, таким как уголовное расследование происшествия в школе, - может считаться оправданной. Исклю-

14 Постановление ЕСПЧ от 11 января 2011 г. по делу «Али против Соединенного Королевства» (Ali v. United Kingdom) (жалоба № 40385/06) // Бюллетень Европейского Суда по правам человека. -2011 . - № 7. 
чение заявителя являлось и законным, и предсказуемым, несмотря на некоторые процессуальные недочеты. В частности, школа не установила срок для первоначального периода исключения и не уведомила заявителя и его родителей об их праве обжалования в управляющий совет; последний не назначил слушание; и период исключения продлился свыше 45-дневного максимума. Однако следует надлежащим образом учитывать крайне сложную ситуацию, в которой оказалась школа в связи с продолжением полицейского расследования. По истечении 45-дневного срока законодательство требовало или восстановить заявителя, или исключить его окончательно. Ни то, ни другое не было сделано. Заявитель не мог быть восстановлен, пока продолжалось уголовное расследование, поскольку другие ученики и персонал являлись потенциальными свидетелями. Но для школы было бы в той же степени недопустимо окончательное исключение, пока не было установлено, что он совершил правонарушение. Что касается пропорциональности меры, Европейский Суд учел факторы, такие как имевшиеся процессуальные гарантии для обжалования исключения и избежания произвола; длительность исключения; склонность к сотрудничеству, продемонстрированная учеником или его родителями в отношении попыток его реинтеграции; попытки школьных властей свести к минимуму последствия его исключения и, в частности, адекватность альтернативного обучения, предложенного школой на период исключения; и пределы влияния на права третьих лиц. Заявитель был исключен только до окончания уголовного расследования. Тот факт, что он не был восстановлен в школе после окончания уголовного расследования, имел место по его вине или по вине его родителей, которые не явились на встречу, предложенную директором с целью содействия его реинтеграции. Кроме того, заявителю было предложено альтернативное обучение на период исключения, хотя он решил не использовать это предложение. Хотя альтернативное обучение не охватывало полностью национальную программу, оно было адекватно с учетом того, что период исключения рассматривался как временное явление, до окончания уголовного расследования. Статья 2 Протокола № 1 к Конвенции не обязывает школы обеспечивать альтернативное обучение, охватывающее полную национальную программу, всем ученикам, временно исключенным из школы. Однако ситуация могла быть иной, если бы ученик возраста обязательного обучения был окончательно исключен из одной школы и не мог впоследствии получить полноценное образование в соответствии с национальной программой в другой школе. Таким образом, исключение заявителя не составляло отказ в праве на образование и не было несоразмерно с преследуемой законной целью.

Одно из дел в Европейском Суде связано с национальностью лица, право на образование которого было нарушено. Это дело «Тимишев (Timishev) против Российской Федерации» ${ }^{15}$.

По делу обжаловался отказ властей разрешить заявителю - гражданину РФ чеченской национальности, уроженцу Чеченской Республики, возвратиться на территорию Кабардино-Балкарской Республики, на основе инструкции МВД, не допускающей на территорию этой республики каких-либо лиц чеченской национальности. Более того поскольку национальность того или иного лица нигде не указывается в российских документах, удостоверяющих личность, распоряжением запрещалось пропускать через административную границу не только любых лиц чеченской национальности, но также и тех лиц, кого просто принимали за лиц этой национальности. По делу не утверждалось, что на представителей других национальностей распространялись аналогичные ограничения. По мнению Европейского Суда, это представляет собой явное неравенство при обращении с людьми по признаку национального происхождения, что касается права на свободу передвижения. Ввиду ограничения права на свободу передвижения, дети заявителя не могли реализовать право на образование.

Одной из распространенных категорий дел в образовательной сфере являются дела, связанные с защитой права на уважение к философским убеждениям родителей. Базисному праву на образование соответствует дополнительное право на уважение религиозных и философских убеждений, под которыми Европейский Суд понимает убеждения, заслуживающие уважения в демократическом обществе и являющиеся совместимыми с достоинством личности, но в то же время не противоречащими основополагающему праву ребенка на образование ${ }^{16}$.

Примером может служить дело «Никишина против Российской Федерации ${ }^{17}$, в котором заявитель-

15 Постановление ЕСПЧ от 13 декабря 2005 г. по делу «Тимишев (Timishev) против Российской Федерации» (жалобы №№ 55762/00 и 55974/00) // Бюллетень Европейского Суда по правам человека. - 2006. - № 8.

16 Гармаш А., Суслова И. Защита прав детей в Европейском суде // ЭЖ-Юрист. - 2012. - № 31. - С. 15.

17 Решение ЕСПЧ от 12 сентября 2000 г. по вопросу приемлемости жалобы № 45665/99, поданной Наталией Васильевной Никишиной против Российской Федерации // Журнал российского права. - 2001. - № 1. - С. 101-104. 
ница - гражданка РФ, получившая при расставании со своим гражданским супругом опеку над их совместным, рожденным вне брака ребенком, стала членом секты «Свидетели Иеговы». Заявительница вовлекала в религиозную деятельность малолетнего сына, против чего возражал отец ребенка. Пытаясь защитить сына, он обратился в районный орган опеки и попечительства с требованием передать ему ребенка, которое позднее было удовлетворено районным судом. Суд вышестоящей инстанции оставил решение без изменения. Тем самым было нарушены гарантированные заявительнице и ее сыну Европейской конвенцией права на уважение частной и семейной жизни, на свободу мысли, совести и религии, а также право воспитывать и обучать ребенка в соответствии с собственными религиозными и философскими убеждениями.

В деле «Фольгере и другие против Норвегии» ${ }^{18}$ оспаривался отказ в полном освобождении от занятий по изучению основ христианства, иных религий и философии в государственных начальных школах. Суд усмотрел нарушение права на образование.

Дети заявителей - членов Норвежской ассоциации гуманизма, посещали начальную школу. В дальнейшем программа начальной школы в Норвегии была изменена, и два различных предмета - христианство и философия жизни - были заменены единым предметом, охватывающим христианство, религию и философию (сокращенное название - KRL). В его рамках преподавались Библия и христианство как культурное наследие, а также евангелическое лютеранское вероучение (официальная религия Норвегии, к которой принадлежат 86\% населения), другие христианские учения, другие мировые религии и философские учения, этика и философия. Ранее действовавшие правила разрешали родителям требовать освобождения своих детей от уроков христианства. Согласно Закону об образовании 1998 г. ученик мог быть освобожден от изучения только тех разделов $\mathrm{KRL}$, которые, по мнению родителей, предполагали приверженность религиям или философии жизни, отличным от их собственных. Заявители и их родители безуспешно добивались полного освобождения от курса KRL.

Организаторы курса KRL предполагали, что путем преподавания основ христианства, других религий и философии можно обеспечить обстановку открытости и приобретение всесторонних знаний в школах. Такое намерение, отметил Европейский Суд, согласу-

18 Постановление ЕСПЧ от 29 июня 2007 г. по делу «Фольгере и другие против Норвегии» (Folgero and Others v. Norway) (жалоба № 15472/02) // Бюллетень Европейского Суда по правам человека. - 2008. - № 1. ется с принципами плюрализма и объективности, закрепленными в ст. 2 Протокола № 1 к Конвенции.

Соответствующие положения Закона об образовании 1998 г. делают акцент на сообщении сведений не только о христианстве, но и других мировых религиях и философских учениях. Его цель заключалась в том, чтобы противостоять сектантству и содействовать диалогу культур и взаимопониманию путем объединения учащихся в рамках единого предмета, вместо того чтобы предоставлять освобождение от него, которое привело бы к разделению учеников на группы, рассматривающие различные темы.

Суд указал, что сведения о христианстве составляли значительную часть учебного плана по сравнению со сведениями о других религиозных и философских учениях, сами по себе не вызывают вопросов с точки зрения ст. 2 Протокола № 1 к Конвенции. С учетом места, которое христианство занимает в истории и традициях Норвегии, такой подход не выходит за рамки допустимого для государства усмотрения в сфере планирования и составления учебных программ.

Однако очевидно, что христианству отводилось главное место, особенно с учетом так называемого правила христианской цели, установленного Законом об образовании 1998 г., согласно которому целью начального или незаконченного среднего образования являлось, по соглашению и в сотрудничестве с семьей, обеспечение детям христианского и морального воспитания. Различный подход также отражается в формулировках законодательства. Кроме того, примерно половина тем учебного плана относилась исключительно к христианству, тогда как остальные были разделены между другими религиозными и философскими учениями.

Суд отметил, что различия в преподавании христианства и других религиозных и философских взглядов были не только количественными, но и качественными. С точки зрения этих несоответствий не совсем ясно, каким образом предполагалось достичь заявленной цели содействия взаимопониманию, уважению и способности поддерживать диалог между людьми с различными представлениями и убеждениями.

Европейский Суд также рассмотрел вопрос о том, было ли право родителей требовать частичного освобождения от KRL достаточным для устранения указанного дисбаланса. Прежде всего он отметил, что практическое получение такого освобождения сопровождалось определенными трудностями. Родители должны были обладать достаточными сведениями относительно деталей учебного плана, чтобы установить и заблаговременно довести до сведения школьной 
администрации те виды учений, которые не совместимы с их личными убеждениями и верованиями. Можно предположить, что родители могли сталкиваться с трудностями при постоянном ознакомлении с тем, что происходит в классах, и вычленении несовместимого с их взглядами, особенно в случае если проблемы возникали с общехристианским разделом KRL.

Во-вторых, за исключением случаев, когда требование о частичном освобождении затрагивает очевидную религиозную деятельность (что не требовало специального обоснования), заявление родителей могло быть удовлетворено, только если оно содержало разумные мотивы такого требования. Информация о личных религиозных и философских взглядах относится к наиболее деликатным аспектам частной жизни. Хотя родители не были обязаны раскрывать свои убеждения, и школьным руководителям особо указывалось на необходимость учитывать право родителей на уважение их личной жизни, существовал риск того, что родители могут счесть себя обязанными раскрыть школьной администрации деликатные аспекты своих религиозных и философских взглядов.

В-третьих, при наличии родительского требования о частичном освобождении школы должны были применять в сотрудничестве с родителями гибкий подход, учитывая их религиозные и философские убеждения и характер оспариваемой деятельности. Таким образом, участие в определенных видах деятельности, например, молитвах, исполнении гимнов, церковных службах и школьных спектаклях, обрядах, может быть заменено присутствием, исходя из того, что освобождение может относиться к самой деятельности, но не к знаниям, которые передаются благодаря ей. Однако, по мнению Европейского Суда, подобное различие между деятельностью и знаниями не только является слишком сложным для практического применения, но, по-видимому, также значительно уменьшает эффективность права на частичное освобождение как таковое. Кроме того, с чисто практической точки зрения у родителей могли возникать сложности, если они требовали от учителей принять на себя дополнительное бремя такого дифференцированного преподавания.

Таким образом, Европейский Суд посчитал, что система частичного освобождения способна подвергать родителей риску вынужденного раскрытия подробностей своей личной жизни, и что потенциальные конфликты могли заставить их воздержаться от предъявления таких требований. В определенных случаях, особенно в отношении деятельности религиозного характера, объем частичного освобождения мог быть ограничен в связи со сложностью дифференцирован- ного обучения. Кроме того, Европейский Суд не убежден, что упомянутая государством-ответчиком возможность обучать своих детей в частных школах освобождает государство от обязанности обеспечивать плюрализм в государственных школах, открытых для каждого.

В связи с этим, несмотря на заслуживающие одобрения цели, к которым законодатель стремился при введении KRL в начальной и неполной средней школе, Европейский Суд заключить, что государствоответчик не проявило достаточную заботливость о передаче информации и знаний, предусмотренных учебным планом, в духе объективности, критического подхода и плюрализма для целей ст. 2 Протокола № 1 к Конвенции».

Дело «Чифтчи против Турции» ${ }^{19}$ касалось вопроса о неправомерности возложения обязанности на ученика пройти программу религиозного обучения как условия допуска к школьным занятиям по изучению Корана. Жалоба была признана явно необоснованной, неприемлемой.

Заявитель жалобы обратился в администрацию государственной школы, где учился его сын, с просьбой разрешить сыну посещать занятия по изучению Корана с тем, чтобы сын мог ознакомиться с Кораном и его толкованиями авторитетами мусульманства. Законодательство Турции предусматривает включение в школьную программу обязательных занятий по религии, начиная с начальной школы и далее. Однако для того, чтобы посещать занятия по изучению Корана, ученику необходимо завершить обучение в начальной школе. Сын заявителя, которому на момент возникновения спора еще не было двенадцати лет, еще не завершил обучение в начальной школе.

В решении Европейского Суда указано, что правовое регулирование системы образования в стране не должно преследовать цель определенной индоктринации учеников, которая может быть сочтена как неуважение к религиозным и философским воззрениям их родителей.

В данном деле возлагаемая законом обязанность пройти курс обучения по программе начальной школы прежде, чем приступить к занятиям по изучению Корана, имела целью обеспечить то, чтобы дети, желающие получить религиозное образование на занятиях по изучению Корана, достигли бы определенной «зрелости» посредством образования, предоставляемого в начальной школе. Как таковое это правовое

19 Решение ЕСПЧ от 17 июня 2004 г. по делу «Чифтчи против Турции» (Giftci - Turkey) (жалоба № 71860/01) // Бюллетень Европейского Суда по правам человека. - 2004. - № 11. 
требование не образует попытку индоктринации, направленную на то, чтобы отвратить учеников от религиозного образования. Данное предварительное условие направлено на то, чтобы ограничить возможности потенциальной индоктринации несовершеннолетних детей в том возрасте, когда они задают много вопросов и могут легко попасть под воздействие идей, являющихся предметом занятий по изучению Корана.

В Европейский Суд обжаловался отказ в освобождении ученицы государственной школы, семья которой исповедовала алевизм, от обязательных уроков по религии и этике. В данном деле «Хасан и Эйлем Зенгин против Турции» ${ }^{20}$ Суд усмотрел нарушение права на образование.

По мнению Суда, анализ указаний Министерства образования относительно уроков по религиозной культуре и этике и школьных учебников показывает, что программы обучения начальной школы и первого цикла средней предусматривают заметный приоритет знания ислама по сравнению с другими религиозными и философскими учениями. Само по себе это не может рассматриваться как идеологическое воздействие, поскольку ислам является в Турции религией большинства, несмотря на светский характер государства. С учетом того, что посещение этих занятий, по-видимому, оказывает значительное влияние на сознание детей, целесообразно установить, сообщаются ли такие сведения в объективном, критическом и плюралистическом духе. Направление алевизма с его глубокими корнями в турецком обществе и истории имеет определенные особенности и отличия от ислама, преподаваемого в школе. Выражение «религиозные убеждения", употребленное во втором предложении ст. 2 Протокола № 1 к Конвенции, применимо к этому направлению. В курсе «Религиозной культуры и этики» не учитывается религиозное многообразие, характерное для турецкого общества. В частности, учащиеся не получают сведений о конфессиональных или обрядовых особенностях алевизма, хотя доля исповедующего его турецкого населения весьма велика. Определенные сведения об алевизме сообщаются в девятом классе, но их отсутствие в начальной и средней школах не позволяет восполнить недостатки обучения. Таким образом, нельзя сделать вывод, что преподавание в школе предмета "Религиозная культура и этика» отвечает критерию объективности и плюрализма, позволяя ученикам выработать критический подход

20 Постановление ЕСПЧ от 9 октября 2007 г. «Хасан и Эйлем Зенгин против Турции» (Hasan and Eylem Zengin v. Turkey) (жалоба № 1448/04) // Бюллетень Европейского Суда по правам человека. - 2008. - № 4. к религиозным вопросам, и обеспечивает уважение религиозных и философских взглядов родителей учеников, исповедующих алевизм, в изучении которого имеются очевидные пробелы.

Необходимо также установить, являются ли достаточными предусмотренные турецкой образовательной системой средства обеспечения уважения к убеждениям родителей. Указанный курс имеет статус обязательного предмета, однако возможность освобождения от его изучения появилась в 1990 г. для детей, родители которых исповедуют христианство или иудаизм, при условии, что они подтвердят свою приверженность к одной из этих религий. По утверждению государства-ответчика, возможность освобождения может быть распространена на представителей иных верований на основании такого заявления. Однако какой бы ни была сфера применения данного освобождения, тот фракт, что родители были обязаны уведомлять школьную администрацию о своих религиозных или философских убеждениях, делает его неподходящим средством обеспечения уважения к свободе их убеждений. В отсутствие ясного указания школьная администрация сохраняла право на отказ в удовлетворении подобных заявлений. Следовательно, процедура освобождения не являлась подходящим методом и не обеспечивала достаточной защиты тем родителям, которые могли обоснованно полагать, что преподаваемый предмет способен вызвать у их детей конфликт между школьными иенностями и внутренними убеждениями. Для детей, чьи родители имели религиозные или философские убеждения, отличные от суннитского ислама, не предусматривалась возможность соответствующего выбора, тогда как процедура освобождения возлагала на родителей тяжелое бремя и обязанность раскрывать свои религиозные или философские взгляды.

Ряд дел был связан с запретом учащимся религиозно ориентированных государственных средних школ ${ }^{21}$, а также университетов на ношение мусульманских головных платков (хиджабов) на территории школ / университетов.

В решениях Европейского Суда по делам «Карадуман против Турции ${ }^{22}$, «Партия Благоденствия и другие

\footnotetext{
21 Решение ЕСПЧ от 24 января 2006 г. по делу «Кесэ и 93 других против Турции» (Kose and 93 others - Turkey) (жалоба № 50278/99) // Бюллетень Европейского Суда по правам человека. - 2006. - № 7.

22 Решение ЕСПЧ от 3 мая 1993 г. по делу «Карадуман против Турции» (Karaduman v. Turkey) (жалоба № 16278/90, DR 74, p. 93) // СПС «КонсультаетПлюс».
} 
против Турции» ${ }^{23}$ и делу «Дахлаб против Швейцарии» 24 Суд признал, что в демократическом обществе государство имеет право устанавливать ограничения на ношение исламского хиджаба, если его ношение не соответствует преследуемой цели защиты прав и свобод других лии, общественного порядка и общественной безопасности. В деле «Карадуман против Турции» меры, принятые в университетах для борьбы с некоторыми фундаменталистскими религиозными течениями, оказывавшими давление на студентов, которые не придерживаются догматов своей религии или исповедуют другую религию, были признаны обоснованными в соответствии с п. 2 ст. 9 Конвенции. Следовательно, было установлено, что высшие учебные заведения могут регулировать отправление ритуалов и ношение символов религии путем введения ограничений в отношении места и способа исповедания своей религии с целью обеспечения мирного сосуществования студентов с различными убеждениями и, соответственно, поддержания общественного порядка и защиты убеждений других лиц.

В деле «Дахлаб против Швейцарии», которое касалось учительницы начальных классов, Европейский Суд подчеркнул, среди прочего, что ношение ею хиджаба представляло собой «мощный внешний символ», задался вопросом, оказывало ли ношение хиджаба эффект обращения в мусульманскую веру, учитывая, что оно, судя по всему, являлось религиозной обязанностью женщин, которую трудно примирить с принципом равенства мужчин и женщин. Европейский Суд также отметил, что ношение исламского хиджаба не так легко было примирить с уроками терпимости, уважения окружающих и, прежде всего, равенства и недискриминации, которые все учителя должны давать своим ученикам.

По делу «Лаутси (Lautsi) и другие против Италии ${ }^{25}$ обжаловалась возможность помещать в кабинетах образовательных учреждений Италии распятий. В решении Европейского Суда отмечается разнообразие подходов европейских государств. В силу этого Европейский Суд по правам человека пересмотрел свое решение от 3 ноября 2009 г. о нарушении Конвенции и признал национальные традиции и «преобладаю-

23 Постановление ЕСПЧ от 13 февраля 2003 г. по делу «Рефах партиси (Партия благоденствия) (Refah Partisi (Welfare Party)) и другие против Турции» // http://www.echr.coe.int>.

24 Решение ЕСПЧ от 15 февраля 2001 г. по делу «Дахлаб против Швейцарии» (Dahlab v. Switzerland) (жалоба № 42393/98, ECHR 2001-V) // http://www.echr.coe.int>.

25 Постановление ЕСПЧ от 18 марта 2011 г. по делу «Лаутси (Lautsi) и другие против Италии» (жалоба № 30814/06) // Бюллетень Европейского Суда по правам человека. - 2011. - № 7. щее народное чувство», право каждого государства «установить равновесие между противоположными интересами». Власти государств - участниц Конвенции подчеркивали, что государства не должны лишать себя части культурной идентичности. В судебном решении акцентируется, что «Европейский Суд не является конституционным судом и должен уважать принцип субсидиарности и признавать особо широкие пределы усмотрения государств-участников не только в отношениях между государством и религией, но также при исполнении функций в сфрере образования и обучения».

В деле «Лейла Шахин (Leyla Sahin) против Турции» ${ }^{26}$ обжаловался циркуляр, подписанный проректором Стамбульского университета, в котором, в частности, говорилось следующее: "На основании Конституции, законов и подзаконных актов, в соответствии с судебной практикой Государственного Совета и Европейской комиссии по правам человека и решениями административных советов университета студенты с «покрытыми головами» (которые носят исламский хиджаб) и студенты (в том числе иностранные студенты) с бородами не должны допускаться на лекции, курсы и консультации. Имя и номер любого студента с бородой или в исламском хиджабе не должны вноситься в списки зарегистрированных студентов. Однако если эти студенты продолжают посещении консультации и ходить на лекции, несмотря на то, что их имена и номера не включены в списки, им необходимо разъяснить их положение, и если они отказываются удалиться из аудитории, их имена и номера должны быть отмечены, а их самих следует информировать о том, что они не имеют право посещать лекции. Если они отказываются покинуть лекционный зал, преподаватель докладывает об инциденте с объяснением причин, по которым он не имел возможности дать лекцию, и в срочном порядке доводит инцидент до внимания руководства университета с целью принятия дисциплинарных мер». На основании это циркуляра студентка не была допущена к экзаменам. ЕСПЧ признал нарушение права на образование.

В нескольких решениях ${ }^{27}$ Европейский Суд высказался об учебных планах образовательных уч-

26 Постановление ЕСПЧ от 10 ноября 2005 г. по делу «Лейла Шахин (Leyla Sahin) против Турции» // <http://www. echr.coe.int>.

27 Постановление ЕСПЧ от 7 декабря 1976 г. по делу «Кьелльсен, Буск Мадсен и Педерсен против Дании» (Kjeldsen, Busk Madsen and Pedersen v. Denmark); Постановление Большой Палаты по делу «Фольгере и другие против Норвегии»; Постановление ЕСПЧ от 7 декабря 1976 г. по делу «Хасан и Эйлем Зенгин против Турции» (Hasan and Eylem Zengin v. Turkey) и др. 


\section{Административное и муниципальное право 8 (68) • 2013}

реждений: «...установление и планирование учебных программ относятся к компетенции государствучастников. Европейский Суд в принципе не может оценивать эти вопросы, поскольку решения могут обоснованно быть различными в разных странах и периодах».

Обобщая изложенное, можно сделать вывод, что Европейский Суд по правам человека исходит из обязательств государств, включая позитивные обязательства, обеспечить соблюдение права на образование «каждому лицу, находящемуся под юрисдикцией Договаривающегося государства».

Европейский Суд учитывает тот факт, что развитие права на образование, содержание которого варьиру- ется в зависимости от времени и места, экономических и социальных условий, главным образом, зависит от потребностей и ресурсов общества. Но решающее значение имеет толкование и применение Конвенции таким образом, чтобы закрепленное в ней право на образование было эффективным и осуществимым, а не теоретическим и иллюзорным. Кроме того, Конвенция является "живым документом», который должен толковаться в свете сложившихся в конкретное время условий ${ }^{28}$.

Подытоживая судебную практику Европейского Суда по правам человека, можно сделать вывод об отсутствии в его подходах стремления жестко унифицировать законодательство европейских стран.

\section{Библиографический список:}

1. Гармаш А., Суслова И. Защита прав детей в Европейском суде // ЭЖ-Юрист. - 2012. - № 31.

2. Коротаева А.М. Практика применения Европейской конвенции о защите прав человека и основных свобод: трудоправовой аспект // Российская юстиция. - 2010. - № 9.

3. Косевич Н.Р. Защита прав детей в практике Европейского суда по правам человека // СПС «КонсультантПлюс», 2011.

\section{References (transliteration):}

1. Garmash A., Suslova I. Zaschita prav detey v Evropeyskom sude // EZh-Yurist. — 2012. - № 31.

2. Korotaeva A.M. Praktika primeneniya Evropeyskoy konvencii o zaschite prav cheloveka i osnovnyh svobod: trudopravovoy aspekt // Rossiyskaya yusticiya. - 2010. - № 9.

3. Kosevich N.R. Zaschita prav detey v praktike Evropeyskogo suda po pravam cheloveka // SPS Konsul'tantPlyus, 2011. 